spirit, if not the letter, of the ACRL Standards for Faculty Status. Many of the rights and privileges of the faculty librarian would be difficult to build or replace outside of that context.

Author's Note: The author would like to thank Ene Andrilli and Rebecca Reilly for their help with this project.
A list of the institutions involved in the survey, along with methodological notes and tabulated survey results, may be obtained by sending an SASE to: John Buschman, Rider College Library, 2083 Lawrenceville Rd., Lawrenceville, NJ 086483099 .

\title{
Hearings to be held on standards for faculty status
}

The ACRL Academic Status Committee is charged with reviewing and updating the standards, guidelines, and related documents that pertain to faculty status and academic governance. The Committee will hold the first of two open hearings on the Standards for Faculty Status for College and University Librarians document at the 1990 ALA Midwinter Meeting in Chicago. These hearings are a unique opportunity for the membership to comment upon this important statement before the Committee begins its deliberations. The Midwinter hearing will be held on Sunday, January 7, 9:00-11:00 a.m.

The Standards for Faculty Status for College and University Librarians document was adopted on June 26, 1971. In the almost two decades that have passed since then, it has not been revised, although many changes have taken place in college and university libraries. For example, the move toward participatory governance, which has characterized this period, does not seem to have strengthened the bid of academic librarians for faculty status. In fact, it appears that there may be fewer institutions that grant librarians faculty status today than there were in 1971 .

The Standard as it is now written follows:

\section{Standards for faculty status for college and university librarians}

In order to recognize formally the college or university librarian's academic status, the Association of College and Research Libraries and the American Library Association endorse, and urge all institutions of higher education and their governing bodies to adopt, the following standards for all academic librarians:

1. Professional responsibilities and self determination. Each librarian should be assigned general responsibilities within his particular area of competence. He should have maximum possible latitude in fulfilling these responsibilities. However, the degree to which he has fulfilled them should be regularly and rigorously reviewed. A necessary element of this review must be appraisal by a committee of peers who have access to all available evidence.

2. Library governance. College and university libraries should adopt an academic form of governance. The librarians should form as a library faculty whose role and authority is similar to that of the faculties of a college or the faculty of a school or a department.

3. College and university governance. L ibrarians should be eligible for membership in the academic senate or equivalent body at their college or university on the same basis as other faculty.

4. Compensation. The salary scale for librarians should be the same as that for other academic categories with equivalent education and experience. Librarians should normally be appointed for the academic year. If a librarian is expected to work through the summer session, his salary scale should be adjusted similarly to the summer session scale of other faculty at his college or university.

5. Tenure. Librarians should be covered by tenure provisions the same as those of other faculty. In the pretenure period, librarians should be covered by written contracts or agreements the same as those of other faculty.

6. Promotion. Librarians should be promoted through the ranks and steps on the basis of their academic proficiency and professional effectiveness. A peer review system similar to that used by other faculty is the primary basis of judgment in the promotion process for academic librarians. The librarians' promotion ladder should have the same titles, ranks, and steps as that of other faculty.

7. Leaves. Sabbatical and other research leaves should be available to librarians on the same basis, and with the same requirements, as they are available to other faculty.

8. Research funds. Librarians should have access to funding for research projects on the same basis as other faculty.

9. Academic freedom. Librarians in colleges and 
universities must have the protection of academic freedom. Library resources and the professional judgment of librarians must not be subject to censorship.

To implement these standards, the Association of College and Research Libraries and the American Library Association will:

1. Publicize these standards to all colleges and universities and their libraries, all library schools, all library organizations, and all agencies which accredit academic institutions.

2. Seek to have these standards formally adopted or endorsed by all colleges and universities and their libraries, all library schools, all library organizations, and all agencies which accredit academic institutions.

3. Investigate all violations of these standards which are reported by members of the Association of College and Research Libraries. Such investigations will be coordinated and supervised by the committee on Academic status of the association of College and Research Libraries.*

4. Invoke the following sanctions against institutions of higher education which are found, after such investigation, to be in violation of any or all of these standards:

a. Publicize the violation and the institution concerned in C\&RL News and other appropriate publications.

b. Refuse to accept advertisements in any ALA publication for positions at that institution.

c. Discourage its members from accepting employment at that institution, through notices in its publications and other means. A reasonable amount of time - three to five years-should be provided college and university libraries which do not currently conform to any or all of these standards, to enable them to do so. However, no such grace period should be provided to libraries which currently do conform, either wholly or in part, and which seek to deny or withdraw any such rights and privileges.

\section{The hearings}

The basic issues addressed by the document have probably not changed since its adoption, but some of the nuances have. Almost every word

"The Committee on Academic Status receives, from individuals, reports of potential violations of these standards and recommends appropriate action to the ACRL Board of Directors. Requests for assistance from individuals who allege that violations of these standards have occurred are within the jurisdiction of the ALA Program of Action for Mediation, Arbitration, and Inquiry, and should be directed to the executive director of the American Library Association. could be debated, but it is hoped that discussion at the hearing will focus on the substantive issues. This statement, like all ACRL policies and guidelines, should reflect what the membership thinks is relevant and pertinent, and not simply mirror the opinions of Committee members.

After the Midwinter hearing, the Academic Status Committee will begin deliberations and revise the document to reflect the position of the membership. A second open hearing will be held at the 1990 ALA Annual Conference in Chicago. The revised Standards will then be forwarded to the ACRL Standards and Accreditation Committee for review and recommendation. If the document is approved, it will then be referred to the ACRL Board of Directors for possible adoption.

If you wish to influence the reformulation of this important policy statement, come to the hearing and share your views with the Committee members. If you will not be attending the Midwinter Meeting in Chicago, you may send written comments to: Irene B. Hoadley, Evans Library, Texas A\&M University, College Station, TX 77843-5000, or call her at (409) 845-8111.

\section{State your fax}

The fifth edition of the Directory of Telefacsimile Sites in North American Libraries is in the final stages of preparation. More than 2,000 libraries will be included, along with a separate section listing fax numbers of organizations doing business with or providing services to the library community.

Information required includes: complete address, fax number, contact person, phone number, type of fax equipment, bibliographic system symbol, and notes concerning fax use limitations.

Libraries wishing to be included should contact CBR Consulting Services, P.O. Box 248, Buchanan Dam, TX 78609; (512) 793-6118; fax: (512) 793-6521. The deadline for inclusion is January $15,1990$.

\section{Corrections}

Two unfortunate misspellings occurred in the October 1989 issue of C¿RL News. The author of "Academic Research Libraries in Germany" (pp. 826-28) is Dr. Elmar Mittler, director of the University of Heidelburg Library, not Elma.

Also, one of the letter-writers under the heading of "Better Humor through Chemistry," is Jean E. Crampon, head librarian of the Hancock Library of Biology and Oceanography, not Compton. 


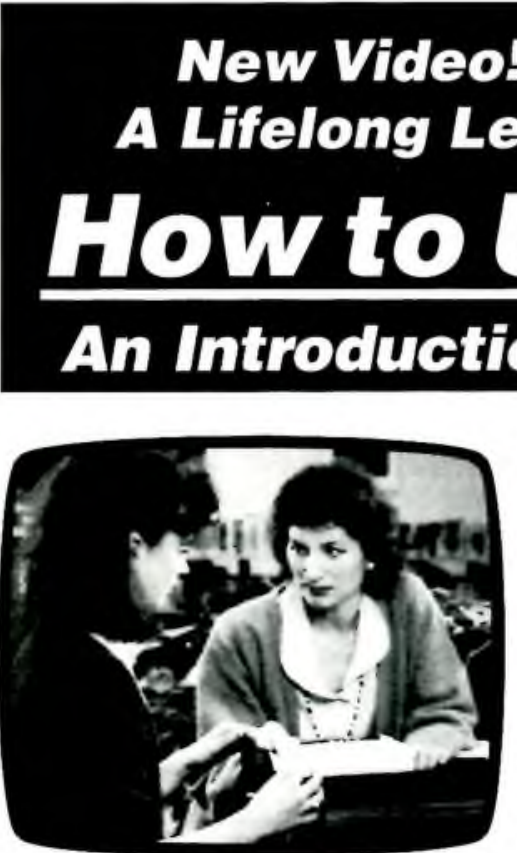

\section{New Video!}

A Lifelong Lesson in Library Use

How to Use the Librarys

\section{Videocassette 20 minutes 1989 ISBN 0-8242-0786-6}

Color/VHS/Hi-Fi, with Viewer's Guide $\$ 49$ U.S. and Canada, $\$ 59$ other countries.

\section{HOW TO USE THE LIBRARY Teaches these Skills. \\ Students who view this video will learn how to approach their research projects with little additional help; and to ask the right questions when they do need assistance. \\ A dynamic teaching aid, the How to Use the Library video will save you many hours of repetitive explanation with a format so clear that students will have few questions when it's over. Most importantly, they will recognize their library as the valuable repository of informa- tion that it really is. How to Use the Library is also the perfect review for those already familiar with basic library skills and sources.}

Students Need the Library, But Lack the Skills to Use It-

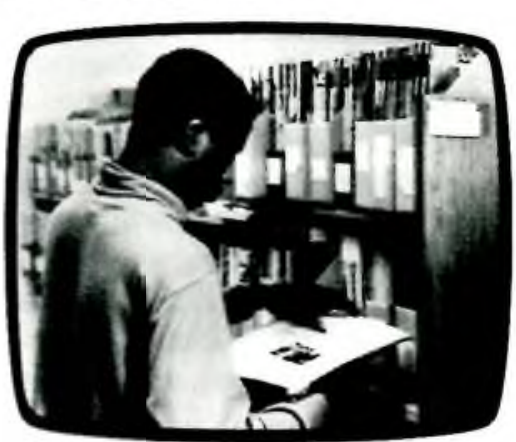

\section{Using the Library-A Step-by-Step Demonstration.}

Ideal for both individual and group instruction, the How to Use the Library video is a crystal-clear initiation into all of your library's resources:

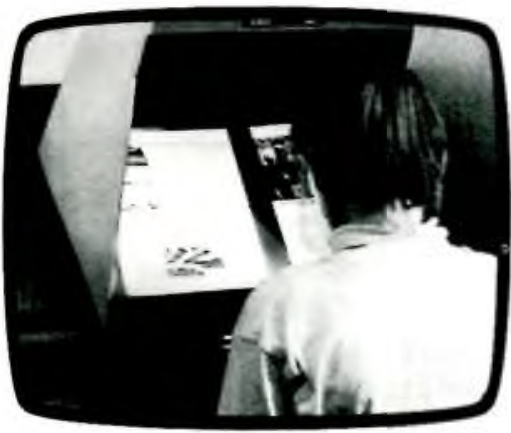

Card and Computerized Catalogs - how and when to use the card catalog; understanding call numbers, subject headings, cross references; and how to find books on the shelves.

Periodical Indexes - how and when to use periodical indexes. Reference Sources - when to consult dictionaries, atlases, encyclopedias, and almanacs; how to make the best use of each.

Vertical or Information File - what unexpected treasures can be found and how to find them.

Library Staff - when to ask for help; why it's important for students to ask specific questions.

And, Finally - putting it all together; using all the pertinent resources in the library. The Viewer's Guide includes a Library Resources Quiz as well as Idea Starters and Suggested Exercises to familiarize students with the media center. 